\title{
Molecular Recognition and Transport of Active Pharmaceutical Ingredients on Anionic Calix [4] arene-Capped Silver Nanoparticles
}

\author{
Florent Perret, ${ }^{1}$ Yannick Tauran, ${ }^{2,3}$ Kinga Suwinska, ${ }^{4,5}$ Beomjoon Kim, ${ }^{3,6}$ \\ Cyrielle Chassain-Nely, ${ }^{2}$ Maxime Boulet, ${ }^{2}$ and Anthony W. Coleman ${ }^{2}$ \\ ${ }^{1}$ ICBMS-UMR 5246, Université Claude Bernard Lyon 1, 69622 Villeurbanne, France \\ ${ }^{2}$ LMI-UMR 5615, CNRS, Université Claude Bernard Lyon 1, 69622 Villeurbanne, France \\ ${ }^{3}$ LIMMS/CNRS-IIS (UMI 2820), University of Tokyo, Tokyo, Japan \\ ${ }^{4}$ Institute of Physical Chemistry, Polish Academy of Sciences, Kasprzaka 44/52, 01224 Warszawa, Poland \\ ${ }^{5}$ Faculty of Biology and Environmental Sciences, Cardinal Stefan Wyszynski University in Warsaw, Wóycickiego 1/3, \\ 01938 Warszawa, Poland \\ ${ }^{6}$ CIRMM, Institute of Industrial Science, University of Tokyo, Tokyo, Japan
}

Correspondence should be addressed to Anthony W. Coleman; antony.coleman@adm.univ-lyon1.fr

Received 29 June 2012; Accepted 14 August 2012

Academic Editor: Kevin Shuford

Copyright ( $\odot 2013$ Florent Perret et al. This is an open access article distributed under the Creative Commons Attribution License, which permits unrestricted use, distribution, and reproduction in any medium, provided the original work is properly cited.

A series of six anionic calix[4] arenes, having sulphonate, carboxylate, or phosphonate functions at either the para-aromatic position or the phenolic face were used to cap silver nanoparticles. Their molecular recognition properties were studied with regard to three active pharmaceutical ingredients, chlorhexidine, chloramphenicol, and. gentamycin sulfate. Of these APIs chlorhexidine is known to form cocrystals with the anionic calix[4]arenes, gentamicin sulfate is an aminoglycosidic antibiotic, and chloramphenicol is a neutral antibiotic. As expected the former two APIs show clear complexation behavior as demonstrated by shifts in the visible spectra whereas the last shows no modification in the wavelength of the plasmon resonance of the silver nanoparticles.

\section{Introduction}

The noble metal nanoparticles are formed by the reduction of a suitable metal salt, for example, chloroauric acid or silver nitrate to the zero oxidation state in the presence of a suitable capping molecule or polymer to stabilize them [1]. They are well known for their ability to act as sensors for molecular interactions by means of shifts in the plasmon resonance absorption [2]. A great amount of work exists concerning their biological properties [3], including biological imaging [4], of particular interest are the antibacterial effects of both the silver and gold nanoparticles $[5,6]$. Indeed the silver nanoparticles have seen commercial usage in areas ranging from hygiene (disinfection of socks) [7] to treatment of computer keyboards [8].

The calix[n]arenes are a group of supramolecular systems [9] widely studied for their ability to complex a very wide range of molecules and ions [10]. The relative ease with which the calix[n]arenes can be modified at either aromatic paraposition or at the phenolic face, [11] has made them perhaps the most attractive of organic hosts. Interest in the biochemistry of the calix $[n]$ arenes has grown dramatically with emergence of a wide range of water soluble derivatives [12]. Their direct behavior to act as Active Pharmaceutical Ingredients (APIs) is now emerging, [13] with activities ranging from anti-viral, [14] anti-bacterial, [15] enzyme activators [16] or blockers [17] anti-coagulant, [18] through anti-cancer [19] to detoxification [20]. As with other supramolecular systems the calix[n]arenes provide means to transport APIs in the solidstate as co-crystals, [21], as solubilizing agents, [22], or as colloidal suspensions, via solid lipid nanoparticle formation [23] or via the formation of cocolloidal complexes with highly hydrophobic partners [24]. Their possible pharmaceutical applications have been made more attractive by a lack of 


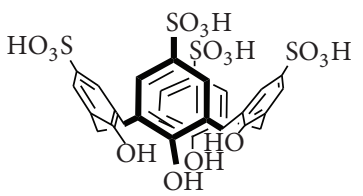

$1_{\mathrm{SO}_{3} \mathrm{H}}$ : para-Sulfonatocalix[4] arene

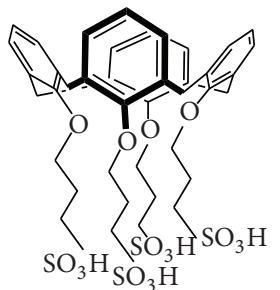

$2 \mathrm{SO}_{3} \mathrm{H}$ : 3-Sulfonatopropoxycalix[4]arene

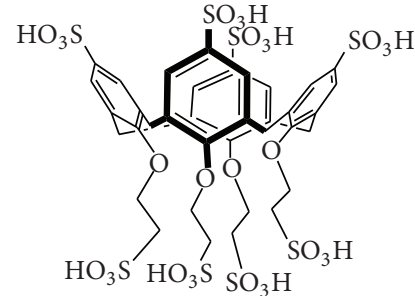

$3_{\mathrm{SO}_{3} \mathrm{H}}$ : para-Sulfonato-3-sulfonatopropoxycalix[4]arene

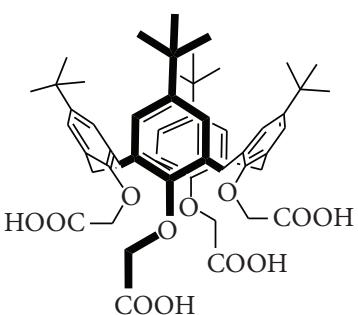

$4_{\mathrm{COOH}}$ : tert-Butyltetra(carboxymethoxy)calix[4]arene

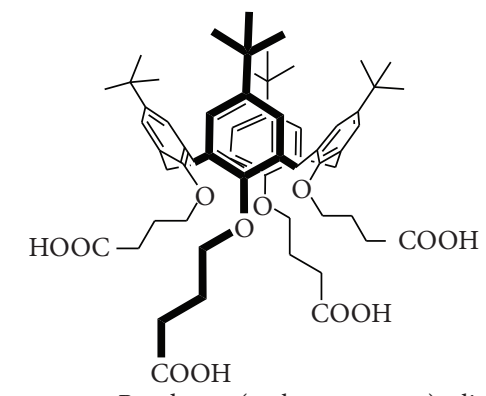

$5_{\mathrm{COOH}}$ : tert-Butyltertra(carboxypropoxy)calix[4]arene

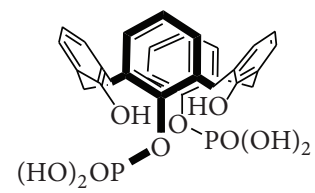

$6_{\mathrm{PO}_{3} \mathrm{H}_{2}}:$ Calix[4] arene dihydroxyphosphonic acid

SCHEme 1: Structures of the calix[n] arene studied. 


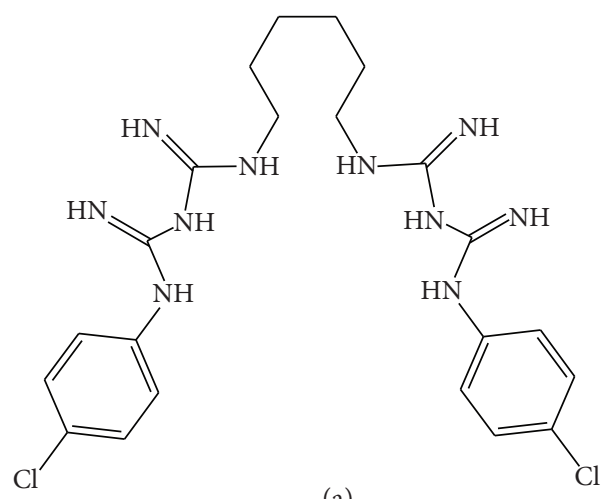

(a)<smiles>O=C(N[C@@H](CO)[C@H](O)c1ccc([N+](=O)[O-])cc1)C(Cl)Cl</smiles>

(b)

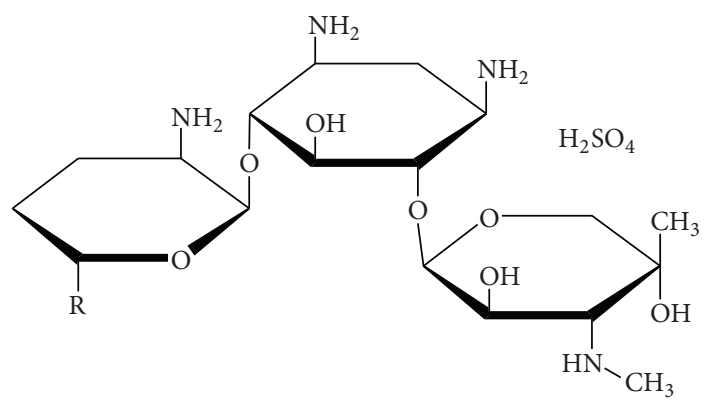

(c)

Scheme 2: Structures of the APIs evaluated: (a) chlorhexidine, (b) chloramphenicol, and (c) gentamycine sulfate.

hemolytic effects [25], an absence of an immune response [26], and a clear lack of in vivo toxicity [27].

The combination of the useful biopharmaceutical properties of the calix [n] arenes with known biological properties thus makes them attractive as biosensors [28] or as transporters or more interestingly by using the calix[n]arenes to act capping stabilisers for nanoparticles and the using their complexation capacities towards APIs to form multifunction APU cocktails.

\section{Experimental}

2.1. Synthesis. para-Sulfonatocalix[4]arene, $\mathbf{1}_{\mathrm{SO}_{3} \mathrm{H}}$, was synthesized as per the literature method and physical characteristics correspond to the literature values [27]. The two
TABLE 1: Maximum wavelength of each Ag_NP_Calix[n]arene as a matter of time of preparation.

\begin{tabular}{lcc}
\hline Compounds & $\lambda$ after 1 hour mixing & $\lambda$ after 24 hours mixing \\
\hline Ag_NP_1 $\mathrm{SO}_{3} \mathrm{H}$ & $400 \mathrm{~nm}$ & $390 \mathrm{~nm}$ \\
Ag_NP__ $\mathrm{SO}_{3} \mathrm{H}$ & $390 \mathrm{~nm}$ & $390 \mathrm{~nm}$ \\
Ag_NP_3 $\mathrm{SO}_{3} \mathrm{H}$ & $390 \mathrm{~nm}$ & $380 \mathrm{~nm}$ \\
Ag_NP_4 & $410 \mathrm{~nm}$ & $420 \mathrm{~nm}$ \\
Ag_NP_5 & $390 \mathrm{~nm}$ & $400 \mathrm{~nm}$ \\
Ag_NP_6 & $390 \mathrm{~nm}$ & $400 \mathrm{~nm}$ \\
\hline
\end{tabular}

3-sulfonatopropoxy derivatives, $\mathbf{2}_{\mathrm{SO}_{2} \mathrm{H}}$ and $\mathbf{3}_{\mathrm{SO}_{3} \mathrm{H}}$, were prepared by the method of Hwang et al. [29] or Shinkai et al. [30] and the physical properties are in accord with the literature values. tert-Butyltetra carboxymethoxy calix[4]arene $\mathbf{4}_{\mathrm{COOH}}$ 


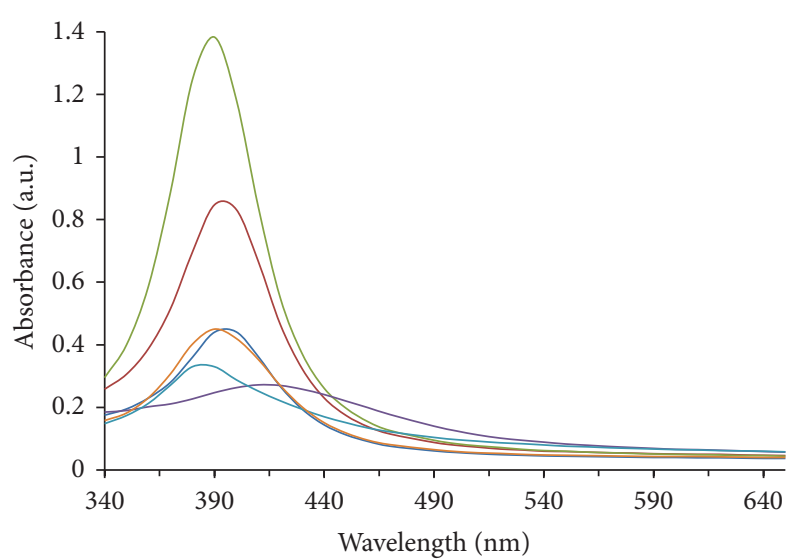

$\begin{array}{ll}- \text { Ag_NP_1 } \mathrm{SO}_{3} \mathrm{H} & - \text { Ag_NP_4 }{ }_{\mathrm{COOH}} \\ - \text { Ag_NP_2 } \mathrm{SO}_{3} \mathrm{H} & - \text { Ag_NP_5 } \mathbf{5}_{\mathrm{COOH}} \\ - \text { Ag_NP_3 } \mathrm{SO}_{3} \mathrm{H} & - \text { Ag_NP_6 }{ }_{\mathrm{PO}_{3} \mathrm{H}_{2}}\end{array}$

(a)

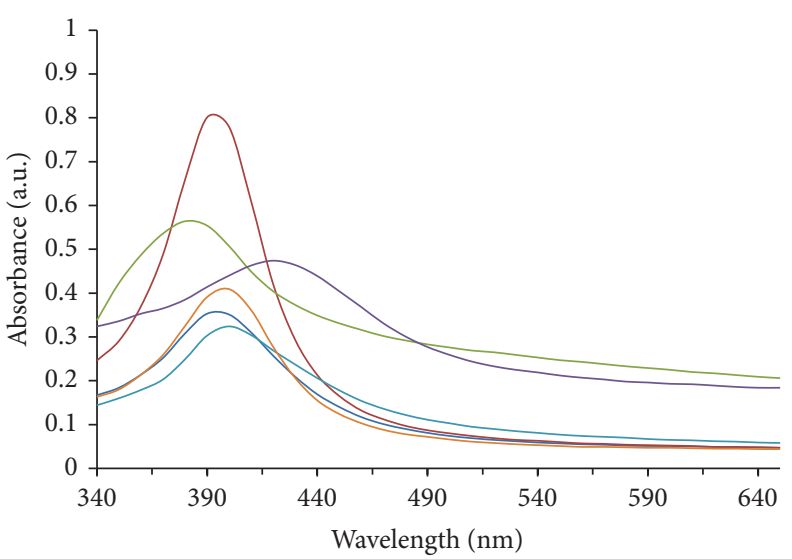

$\begin{array}{ll}- \text { Ag_NP_1 } \mathrm{SO}_{3} \mathrm{H} & - \text { Ag_NP_4 } \mathrm{COOH} \\ - \text { Ag_NP_2 } \text { SO }_{3} \mathrm{H} & - \text { Ag_NP_5 } \mathrm{COOH} \\ \text { Ag_NP_3 } \mathrm{SO}_{3} \mathrm{H} & - \text { Ag_NP_6 } \mathrm{PO}_{3} \mathrm{H}_{2}\end{array}$

(b)

FIgURE 1: The UV visible spectra of Ag_NP_Calix[n]arene after (a) 1 hour and after (b) 24 hours.

TABLE 2: The slopes of the variation of the maximum wavelength of Ag_NP_Calix $[n]$ arene against the concentration of chlorhexidine.

\begin{tabular}{|c|c|c|}
\hline Compounds & Slope $(\mathrm{nm} / \mathrm{M})$ & Rank \\
\hline \multicolumn{3}{|c|}{ After 1 hour mixing with chlorhexidine } \\
\hline Ag_NP_3 SO $_{3} \mathrm{H}$ & $1.1 \times 10^{6}$ & 1 \\
\hline Ag_NP_6 PO $_{3} \mathrm{H}_{2}$ & $4 \times 10^{5}$ & 2 \\
\hline Ag_NP_1 $\mathrm{SO}_{3} \mathrm{H}$ & $3.6 \times 10^{5}$ & 3 \\
\hline $\mathrm{Ag} \_\mathrm{NP} \_\boldsymbol{2}_{\mathrm{SO}_{3} \mathrm{H}}$ & $2 \times 10^{5}$ & 4 \\
\hline Ag_NP_5 ${ }_{\mathrm{COOH}}$ & $2 \times 10^{5}$ & 4 \\
\hline Ag_NP_4 $\mathbf{4}_{\mathrm{COOH}}$ & 0 & 5 \\
\hline \multicolumn{3}{|c|}{ After 24 hours mixing with chlorhexidine } \\
\hline Ag_NP_2 $\mathrm{SO}_{3} \mathrm{H}$ & $1 \times 10^{6}$ & 1 \\
\hline Ag_NP_1 SO $_{3} \mathrm{H}$ & $5 \times 10^{5}$ & 2 \\
\hline $\mathrm{Ag} \_\mathrm{NP} \_3_{\mathrm{SO}_{3} \mathrm{H}}$ & $3 \times 10^{5}$ & 3 \\
\hline Ag_NP_6 PO $_{3} \mathrm{H}_{2}$ & $3 \times 10^{5}$ & 3 \\
\hline Ag_NP_5 ${ }_{\mathrm{COOH}}$ & $3 \times 10^{5}$ & 3 \\
\hline Ag_NP_4 $\mathbf{C O O H}_{\mathrm{COH}}$ & 0 & 4 \\
\hline
\end{tabular}

and tert-butyltetra carboxypropoxy calix[4] arene $\mathbf{5}_{\mathrm{COOH}}$ were synthesized as per Ohto [31] and purity confirmed by spectral means. The diphosphonate derivative, $\mathbf{6}_{\mathrm{PO}_{3} \mathrm{H}_{2}}$, was synthesized as per the method of Markovsky and Kalchenko [32]; all spectral values are in accord with their values.

2.2. Nanoparticle Preparation and Characterization. The procedure of Xiong et al. [33] was slightly modified as follows. $10 \mathrm{~mL}$ of $1 \times 10^{-2} \mathrm{M} \mathrm{AgNO}_{3}$ solution was added to $80 \mathrm{~mL}$ of deionized water. To this solution, $10 \mathrm{~mL}$ of $1 \times 10^{-2} \mathrm{M}$ calix $[\mathrm{n}]$ arene aqueous solution was added as stabilizer with stirring for $30 \mathrm{~min}$. And then, $44 \mathrm{mg}$ of $\mathrm{NaBH}_{4}$ was added to the solution. Then the calix[n]arene-capped silver colloidal
TABLE 3: The slopes of the variation of the maximum wavelength of Ag_NP_Calix[ $n]$ arene against the concentration of gentamycine sulfate.

\begin{tabular}{|c|c|c|}
\hline Compounds & Slope $(\mathrm{nm} / \mathrm{M})$ & Rank \\
\hline \multicolumn{3}{|c|}{ After 1 hour mixing with gentamycine sulfate } \\
\hline Ag_NP_2 SO $_{3} \mathrm{H}$ & $9 \times 10^{6}$ & 1 \\
\hline Ag_NP_5 $\mathbf{C O O H}$ & $9 \times 10^{6}$ & 1 \\
\hline Ag_NP_3 SO $_{3} \mathrm{H}$ & $2 \times 10^{6}$ & 2 \\
\hline Ag_NP_6 PO $_{3} \mathrm{H}_{2}$ & $1.3 \times 10^{6}$ & 3 \\
\hline Ag_NP_1 ${ }_{\mathrm{SO}_{3} \mathrm{H}}$ & $9 \times 10^{5}$ & 4 \\
\hline Ag_NP_4 ${ }_{\mathrm{COOH}}$ & $\mathrm{NA}^{*}$ & \\
\hline \multicolumn{3}{|c|}{ After 24 hours mixing with gentamycine sulfate } \\
\hline Ag_NP_2 SO $_{3} \mathrm{H}$ & $1.4 \times 10^{7}$ & 1 \\
\hline Ag_NP_6 $_{\mathrm{PO}_{3} \mathrm{H}_{2}}$ & $1.3 \times 10^{7}$ & 2 \\
\hline Ag_NP_3 $3_{\mathrm{SO}_{3} \mathrm{H}}$ & $3 \times 10^{6}$ & 3 \\
\hline Ag_NP_5 & $1.2 \times 10^{6}$ & 4 \\
\hline Ag_NP_1 SO $_{3} \mathrm{H}$ & $1 \times 10^{6}$ & 5 \\
\hline Ag_NP_4 ${ }_{\mathrm{COOH}}$ & $\mathrm{NA}^{*}$ & \\
\hline
\end{tabular}

suspensions were characterized by UV-visible absorption assays. We monitored the change in absorbance between $340 \mathrm{~nm}$ and $650 \mathrm{~nm}$, using a 96-titer well-visible spectrometer, (BioTek Power Wave 340).

2.3. Complexation Titration. All APIs were purchased from Sigma Aldrich; chlorhexidine (Merck index no. 55-56-1), chloramphenicol (Merck index no. 56-75-7) and gentamycine sulfate (Merck index no. 1403-66-3).

The complexation between API and calix[n] arene-capped silver colloidal suspensions was monitored with UV-visible absorption spectra after mixing for 1 hour and 24 hours. 


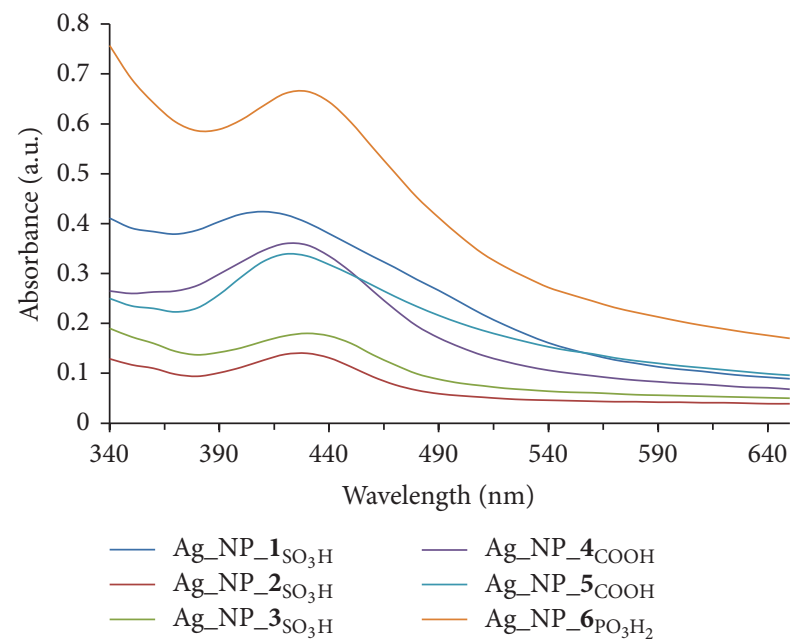

(a)

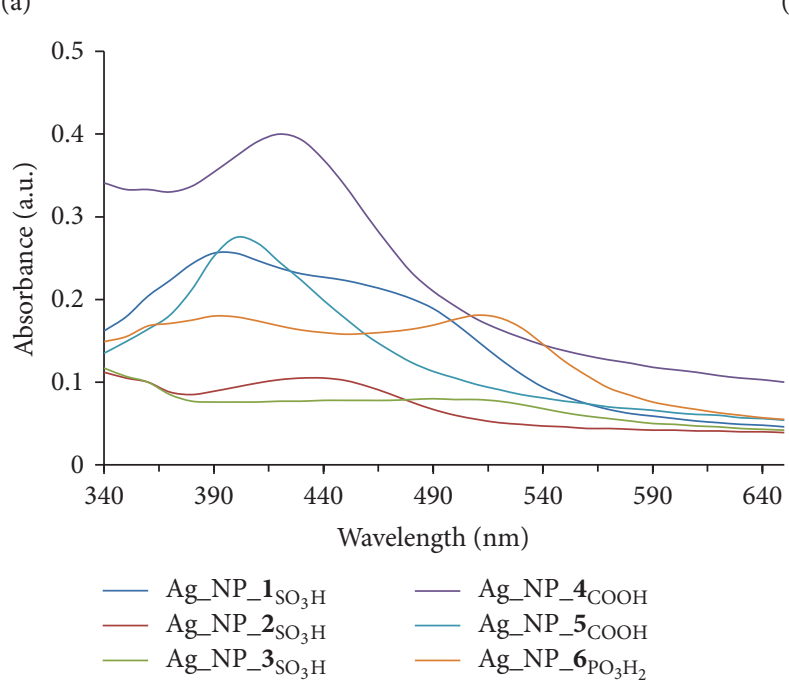

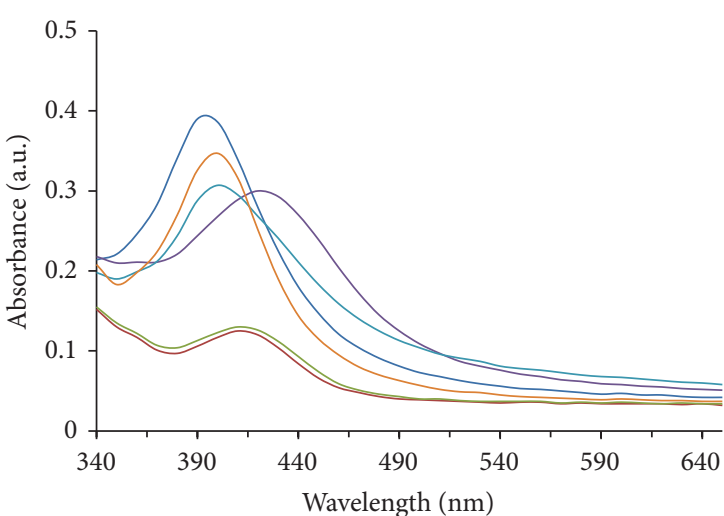

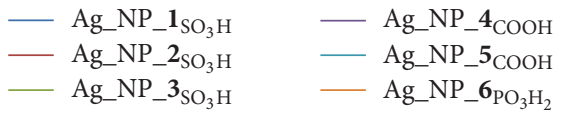

(b)

(c)

Figure 2: The UV-visible spectra of Ag_NP_Calix[n] arene mixed for 1 hour with (a) $1 \times 10^{-4} \mathrm{M}$ chlorhexidine (b) $1 \times 10^{-4} \mathrm{M}$ chloramphenicol (c) $1 \times 10^{-4} \mathrm{M}$ gentamycine sulfate.

The calix[n]arene-capped silver colloidal suspensions are at a final concentration of $1 \times 10^{-4} \mathrm{M}$. The API will be mixed at different final concentrations: $1 \times 10^{-3} \mathrm{M}, 1 \times 10^{-4} \mathrm{M}, 1 \times$ $10^{-5} \mathrm{M}, 1 \times 10^{-6} \mathrm{M}$, and $1 \times 10^{-7} \mathrm{M}$.

\section{Results and Discussion}

The chemical structures of the calix[n]arene derivatives are given in Scheme 1. The chemical structures of the APIs are given in Scheme 2 below.

The stability over the time of the different calix[n]arenecapped silver nanoparticles (Ag_NP_Calix[n]arene) solutions as characterized using UV-visible spectroscopy 1 hour and 24 hours after their preparation (Figure 1). Even if the intensity of absorbance decreases for some silver nanoparticle solutions, in particular with Ag_NP_3 $3_{\mathrm{SO}_{3} \mathrm{H}}$, Table 1 shows that the maximum wavelength of all Ag_NP_Calix[n]arene remains stable. This shows that silver nanoparticles are still present after 24 hours of their preparation. For all but Ag_NP_3 $3_{\mathrm{SO}_{3} \mathrm{H}}$, the plasmon resonance absorption peak is sharp and centered at $390 \mathrm{~nm}$; however in the case of Ag_NP_3 $3_{\mathrm{SO}_{3} \mathrm{H}}$, the plasmonic peak is quite broad and centred at $420 \mathrm{~nm}$ suggesting a different assembly mode and also some aggregation.

Titration experiments were carried out between the six different types of calix[4]arene-capped nanoparticles and three APIs, chlorhexidine, chloramphenicol, and gentamycine.

Chlorhexidine is a clinically important antiseptic, disinfectant, and preservative. It is a potent membrane-active 

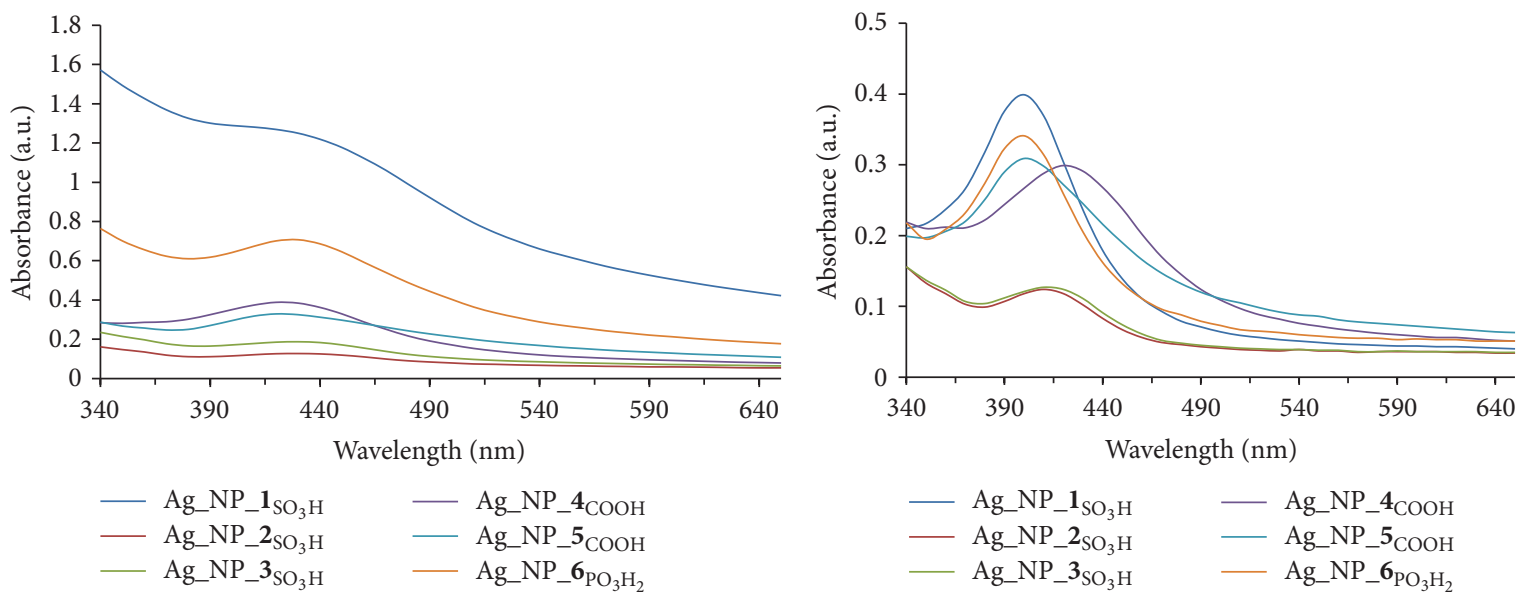

(a)

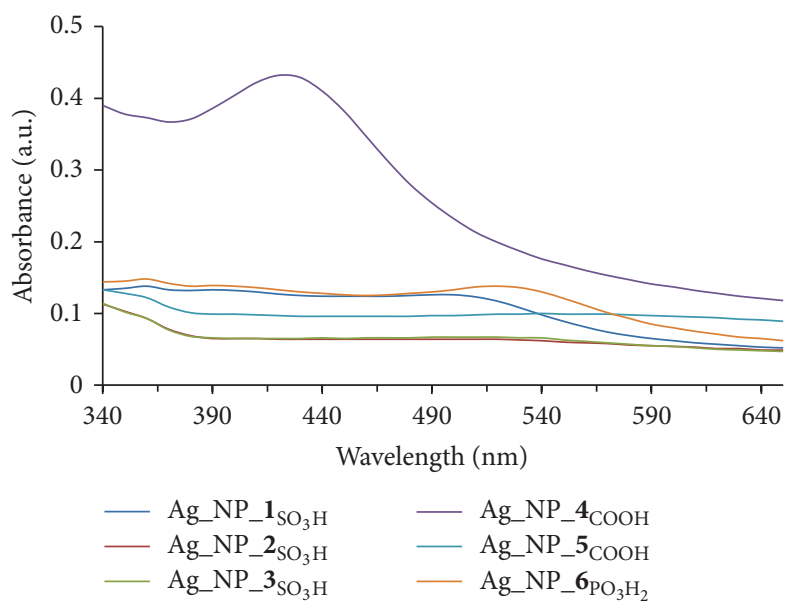

(c)

Figure 3: The UV visible spectra of Ag_NP_Calix[n]arene mixed 24 hours with (a) $1 \times 10^{-4} \mathrm{M}$ chlorhexidine, (b) $1 \times 10^{-4} \mathrm{M}$ chloramphenicol, and (c) $1 \times 10^{-4} \mathrm{M}$ gentamycine sulfate.

agent against bacteria and inhibits outgrowth, but not germination, of bacterial spores. Chloramphenicol is considered a prototypical broad-spectrum antibiotic, alongside the tetracyclines. The most serious adverse effect associated with chloramphenicol treatment is bone marrow toxicity, which is rare $(0.1 \%$ of the cases), unpredictable, unrelated to dose and in general fatal. As a consequence, it is no longer a first-line agent for any infection in developed nations, although it is sometimes used topically for eye infections. Nevertheless, the global problem of advancing bacterial resistance to newer drugs has led to renewed interest in its use.

Gentamycine sulfate is an aminoglycoside antibiotic, used to treat many types of bacterial infections, particularly those caused by Gram-negative organisms. Its bactericidal effect involves binding the $30 \mathrm{~S}$ subunit of the bacterial ribosome, interrupting protein synthesis. Like all aminoglycosides, when gentamicin is given orally, it is not systemically active. This is because it is not absorbed to any appreciable extent from the small intestine. It is administered intravenously, intramuscularly, or topically to treat infections.

The choice of the APIs was based on the facts that chlorhexidine is known to complex with all three types of calix [4] arene derivatives; the conformational flexibility of the molecule led to the presence of three distinct isomers in the solid state [34]. In the case of gentamycine it has already been shown that aminoglycosides complex with $\mathbf{1}_{\mathrm{SO}_{3} \mathrm{H}}[10]$; however for streptomycin the complexation was associated over several weeks with glycosidic bond cutting [35]. With regard to chloramphenicol, preliminary studies had shown a total lack of interaction and the molecule was chosen as a negative control.

Representative visible spectratitration curves at $1 \mathrm{H}$ and $24 \mathrm{H}$ are shown in Figures 2 and 3; for both gentamycine and chlorhexidine there are strong shifts in the plasmon resonance and intensity variations. For gentamycine in particular the changes in wavelength clearly arise from complexation on the nanoparticles by the API [28]. 


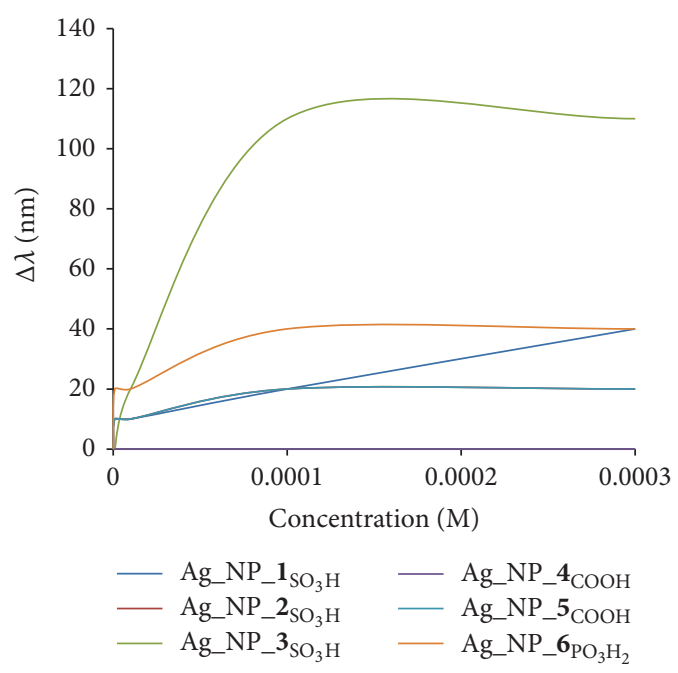

(a)

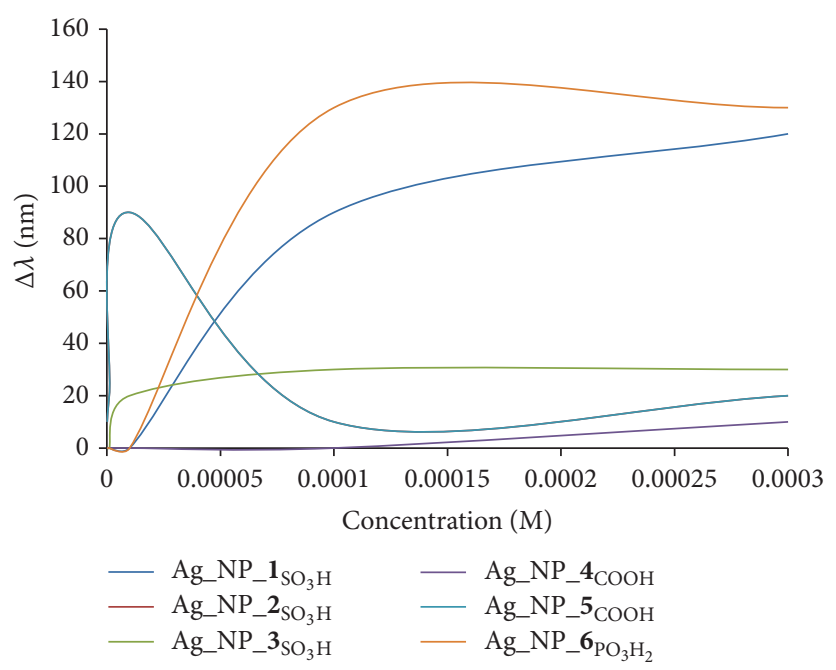

(b)

FIGURE 4: The delta values of the maximum wavelength of Ag_NP_Calix[n]arene as a matter of concentration of API mixed during 1 hour with (a) chlorhexidine and (b) gentamycine sulfate.

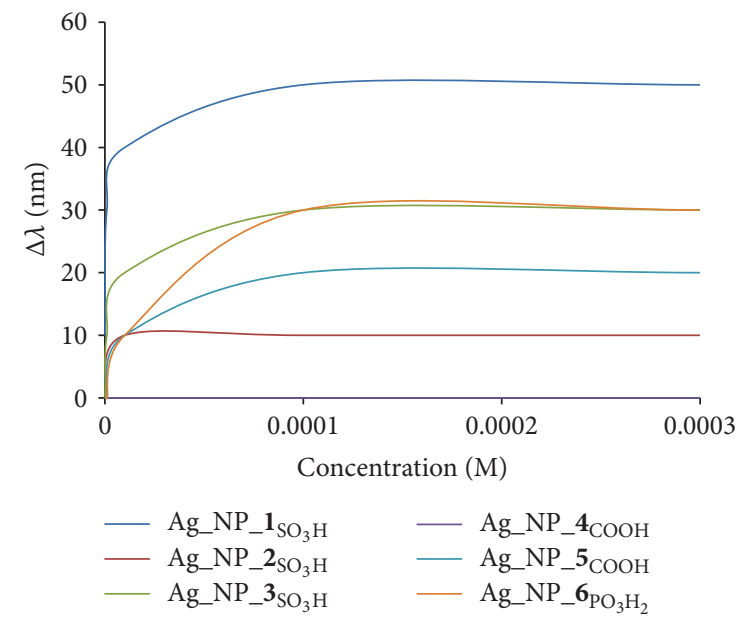

(a)

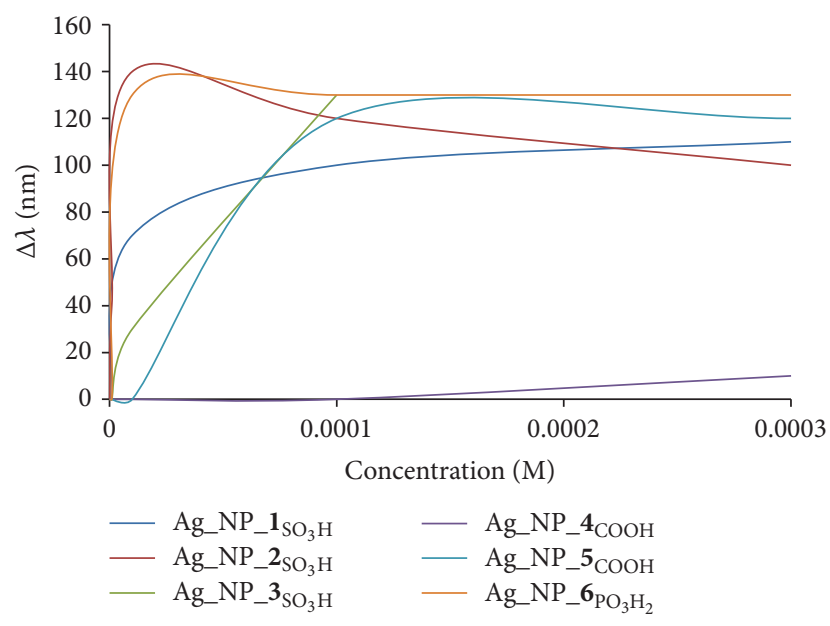

(b)

FIGURE 5: The delta of the maximum wavelength of Ag_NP_Calix[n]arene as a matter of concentration of API mixed during 24 hours with (a) chlorhexidine (b) gentamycine sulfate.

Given the large shifts in wavelength observed for the absorption associated with the plasmon resonance, the change in wavelength was plotted as a function of API concentration; see Figures 4 and 5.

For chloramphenicol, no change in the wavelength is observed; this is expected in view of the lack of complexation. For chlorhexidine and gentamycine, the curves show a typical concentration-dependent absorption associated with saturation. These reflect the different binding affinities of the various calix[4] arene derivatives with regard to the two APIs.

Given the incertitude in the exact concentration of complexation sites on the surfaces of the nanoparticles we consider it unwise to calculate association constants.
However comparative values can be extracted from the initial slopes of the curves and these are summarized in Tables 2 and 3.

There are clear variations in the affinity, while in general the hybrid silver nanoparticles capped with Ag_NP_2 $\mathbf{S O}_{3} \mathrm{H}$ show the highest affinity with chlorhexidine; after $1 \mathrm{H}$ the system is fourth in respect to affinity. Of the systems studied only Ag_NP_4 $4_{\mathrm{COOH}}$ shows little or no affinity for these two APIs.

Thus we have observed selectivity in the interactions between the calix [4] arene capped nanoparticles and the APIs studied. This variation is dependent on the nature of the calix[n]arene, the API, and the kinetics of the interaction. 


\section{Conclusion}

A series of novel calix[n] arene-capped silver nanoparticles have been prepared and their stability demonstrated. We have been able to couple calix[4] arenes having sulfonate, carboxylate, and phosphonate functions onto the silver nanoparticles. Tests with the APIs, chlorohexidine, chloramphenicol, and gentamycine sulfate, show strong affinity towards chlorohexidine and gentamycine, whereas for chloramphenicol little or no affinity exists. The affinities for the APIs depend on the nature of the calix[4] arene and on the nature of the API, and the kinetics of interaction vary as a function of both of the above.

\section{Acknowledgments}

The authors thank the CNRS and the University Lyon 1 for financial support.

\section{References}

[1] J. Turkevich, P. C. Stevenson, and J. Hillier, "A study of the nucleation and growth processes in the synthesis of colloidal gold," Discussions of the Faraday Society, vol. 11, pp. 55-75, 1951.

[2] P. K. Jain, W. Huang, and M. A. El-Sayed, "On the universal scaling behavior of the distance decay of plasmon coupling in metal nanoparticle pairs: a plasmon ruler equation," Nano Letters, vol. 7, no. 7, pp. 2080-2088, 2007.

[3] P. K. Jain, X. Huang, I. H. El-Sayed, and M. A. El-Sayed, "Noble metals on the nanoscale: optical and photothermal properties and some applications in imaging, sensing, biology, and medicine," Accounts of Chemical Research, vol. 41, no. 12, pp. 1578-1586, 2008.

[4] M. A. Hahn, A. K. Singh, P. Sharma, S. C. Brown, and B. M. Moudgil, "Nanoparticles as contrast agents for in-vivo bioimaging: current status and future perspectives," Analytical and Bioanalytical Chemistry, vol. 399, no. 1, pp. 3-27, 2011.

[5] R. T. Tom, V. Suryanarayanan, P. G. Reddy, S. Baskaran, and T. Pradeep, "Ciprofloxacin-protected gold nanoparticles," Langmuir, vol. 20, no. 5, pp. 1909-1914, 2004.

[6] K. K. Y. Wong and X. Liu, "Silver nanoparticles-the real "silver bullet" in clinical medicine?" Medical Chemical Communications, vol. 1, no. 2, pp. 125-131, 2010.

[7] X. Chen and H. J. Schluesener, "Nanosilver: a nanoproduct in medical application," Toxicology Letters, vol. 176, no. 1, pp. 1-12, 2008.

[8] J. Markarian, "Antimicrobials find new healthcare applications," Plastics, Additives and Compounding, vol. 11, no. 1, pp. 18-22, 2009.

[9] C. D. Gutsche, Calixarenes An Introduction, The Royal Society of Chemistry, Cambridge, UK, 2nd edition, 2008.

[10] F. Perret, A. N. Lazar, and A. W. Coleman, "Biochemistry of the para-sulfonato-calix[n]arenes," Chemical Communications, no. 23, pp. 2425-2438, 2006.

[11] S. Shinkai, S. Mori, T. Tsubaki, T. Sone, and O. Manabe, "New water-soluble host molecules derived from calix[6]arene," Tetrahedron Letters, vol. 25, no. 46, pp. 5315-5318, 1984.

[12] F. Perret and A. W. Coleman, "Biochemistry of anionic calix[n]arenes," Chemical Communications, vol. 47, no. 26, pp. 7303-7319, 2011.
[13] E. Da Silva, A. N. Lazar, and A. W. Coleman, "Biopharmaceutical applications of calixarenes," Journal of Drug Delivery Science and Technology, vol. 14, no. 1, pp. 3-20, 2004.

[14] L. K. Tsou, G. E. Dutschman, E. A. Gullen, M. Telpoukhovskaia, Y. C. Cheng, and A. D. Hamilton, "Discovery of a synthetic dual inhibitor of HIV and HCV infection based on a tetrabutoxycalix[4]arene scaffold," Bioorganic and Medicinal Chemistry Letters, vol. 20, no. 7, pp. 2137-2139, 2010.

[15] R. Lamartine, M. Tsukada, D. Wilson, and A. Shirata, "Antimicrobial activity of calixarenes," Comptes Rendus Chimie, vol. 5, no. 1, pp. 163-169, 2002.

[16] P. Molenveld, J. F. J. Engbersen, and D. N. Reinhoudt, "Dinuclear bisimidazolyl-Cu(II) calix[4] arenes as metalloenzyme models. Synthesis and bifunctional catalysis in phosphate diester transesterification," Journal of Organic Chemistry, vol. 64, no. 17, pp. 6337-6341, 1999.

[17] A. I. Vovk, V. I. Kalchenko, S. A. Cherenok, V. P. Kukhar, O. V. Muzychka, and M. O. Lozynsky, "Calix[4]arene methylenebisphosphonic acids as calf intestine alkaline phosphatase inhibitors," Organic and Biomolecular Chemistry, vol. 2, no. 21, pp. 3162-3166, 2004.

[18] E. Da Silva, D. Ficheux, and A. W. Coleman, "Anti-thrombotic activity of water-soluble calix[n]arenes," Journal of Inclusion Phenomena, vol. 52, no. 3-4, pp. 201-206, 2005.

[19] R. Kamada, W. Yoshino, T. Nomura et al., "Enhancement of transcriptional activity of mutant p53 tumor suppressor protein through stabilization of tetramer formation by calix[6]arene derivatives," Bioorganic and Medicinal Chemistry Letters, vol. 20, no. 15, pp. 4412-4415, 2010.

[20] R. Kumar Pathak, V. Kumar Hinge, M. Mondal, and C. Pulla Rao, "Triazole-linked-thiophene conjugate of calix[4]arene: its selective eecognition of $\mathrm{Zn}^{+}$and as biomimetic model in supporting the events of the metal detoxification and oidative stress involving metallothionein," Journal of Organic Chemistry, vol. 76, pp. 10039-10049, 2011.

[21] O. Danylyuk and K. Suwinska, "Solid-state interactions of calixarenes with biorelevant molecules," Chemical Communications, no. 39, pp. 5799-5813, 2009.

[22] W. Yang, D. P. Otto, W. Liebenberg, and M. M. De Villiers, "Effect of para-sulfonato-calix[n] arenes on the solubility, chemical stability, and bioavailability of a water insoluble drug nifedipine," Current Drug Discovery Technologies, vol. 5, no. 2, pp. 129-139, 2008.

[23] S. Jebors, A. Leydier, Q. Wu, B. Bertino Ghera, M. Malbouyre, and A. W. Coleman, "Solid lipid nanoparticles (SLNs) derived from para-acyl-calix[9]-arene: preparation and stability," Journal of Microencapsulation, vol. 27, no. 7, pp. 561-571, 2010.

[24] J. Gualbert, P. Shahgaldian, and A. W. Coleman, "Interactions of amphiphilic calix[4] arene-based Solid Lipid Nanoparticles with bovine serum albumin," International Journal of Pharmaceutics, vol. 257, no. 1-2, pp. 69-73, 2003.

[25] E. Da Silva, P. Shahgaldian, and A. W. Coleman, "Haemolytic properties of some water-soluble para-sulphonato-calix-[n]arenes," International Journal of Pharmaceutics, vol. 273, no. 1-2, pp. 57-62, 2004.

[26] M. H. Paclet, C. F. Rousseau, C. Yannick, F. Morel, and A. W. Coleman, "An absence of non-specific immune response towards para-sulphonato-calix[n] arenes," Journal of Inclusion Phenomena and Macrocyclic Chemistry, vol. 55, no. 3-4, pp. 353-357, 2006. 
[27] A. W. Coleman, S. Jebors, S. Cecillon et al., "Toxicity and biodistribution of para-sulfonato-calix[4] arene in mice," New Journal of Chemistry, vol. 32, no. 5, pp. 780-782, 2008.

[28] Y. Tauran, M. Grosso, A. Brioude, R. Kassab, and A. W. Coleman, "Colourimetric and spectroscopic discrimination between nucleotides and nucleosides using para-sulphonatocalix[4]arene capped silver nanoparticles," Chemical Communications, vol. 47, pp. 10013-10015, 2011.

[29] K. M. Hwang, Y. M. Qi, S. Liu, T. C. Lee, W. Choy, and J. Chen, "Antithrombotic treatment with calixarene compounds," Patent, US54099959, p. 46, 1995.

[30] S. Shinkai, S. Mori, H. Koreishi, T. Tsubaki, and O. Manabe, "Hexasulfonated calix[6]arene derivatives: a new class of catalysts, surfactants, and host molecules," Journal of the American Chemical Society, vol. 108, no. 9, pp. 2409-2416, 1986.

[31] K. Ohto, M. Yano, K. Inoue et al., "Solvent extraction of trivalent rare earth metal ions with carboxylate derivatives of calixarenes," Analytical Sciences, vol. 11, no. 6, pp. 893-899, 1995.

[32] L. N. Markovsky, V. I. Kalchenko, and N. A. Parkhomenko, "O-phopshorylated p-tert-butylcalixarenes," Zhurnal Obshchei Khimii, vol. 60, pp. 2811-2812, 1990.

[33] D. Xiong, M. Chen, and H. Li, "Synthesis of para-sulfonatocalix[4]arene-modified silver nanoparticles as colorimetric histidine probes," Chemical Communications, no. 7, pp. 880-882, 2008.

[34] N. Dupont, A. N. Lazar, F. Perret et al., "Solid state structures of the complexes between the antiseptic chlorhexidine and three anionic derivatives of calix[4]arene," CrystEngComm, vol. 10, no. 8, pp. 975-977, 2008.

[35] B. Leśniewska, S. Jebors, A. W. Coleman, and K. Suwińska, "Streptidinium sulfate monohydrate," Acta Crystallographica Section C, vol. 65, no. 6, pp. o290-o292, 2009. 

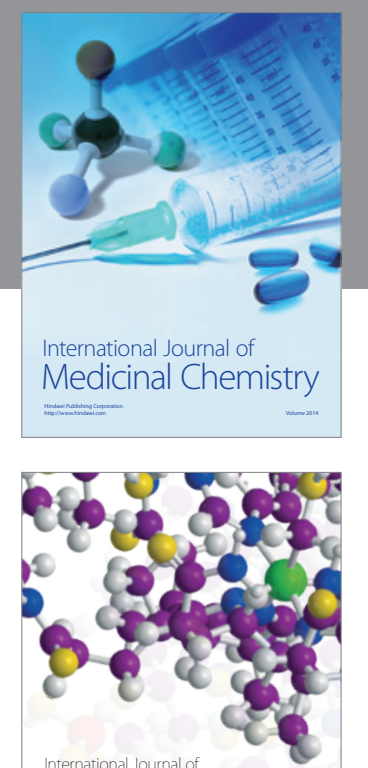

\section{Carbohydrate} Chemistry

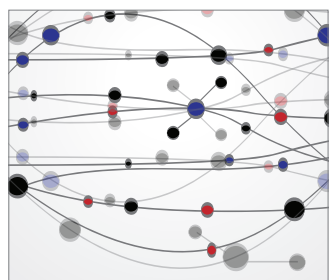

The Scientific World Journal
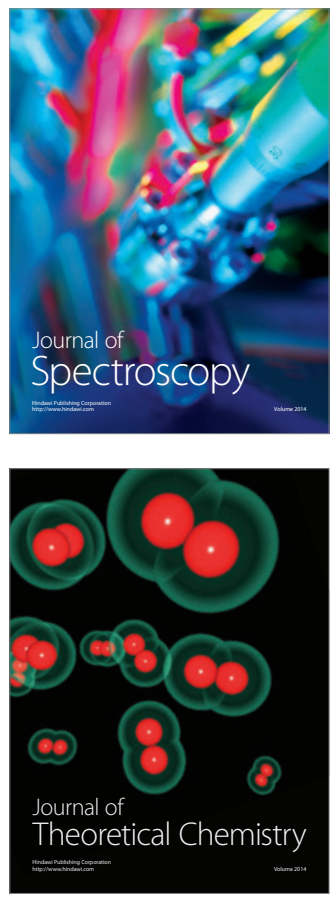
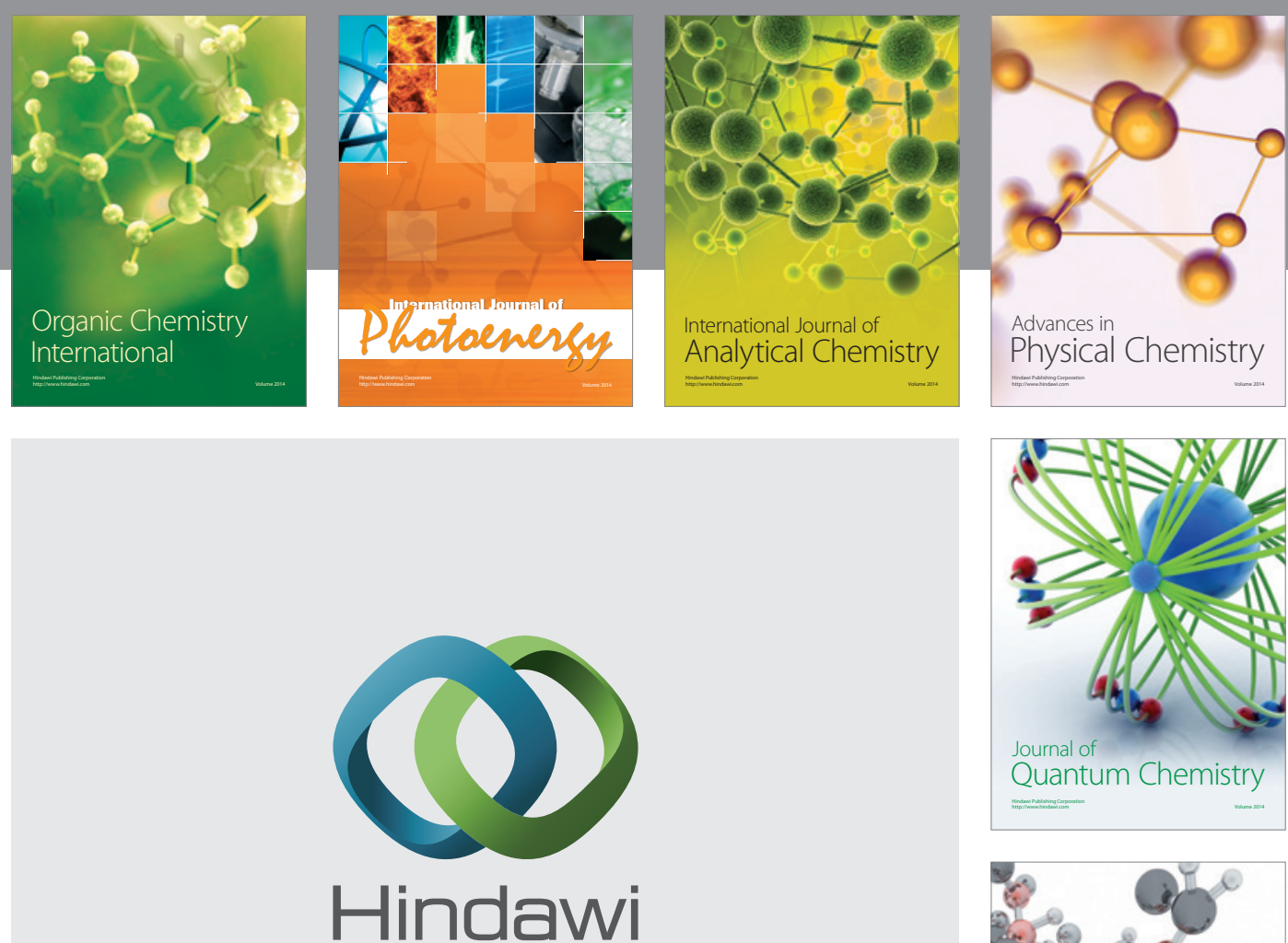

Submit your manuscripts at

http://www.hindawi.com

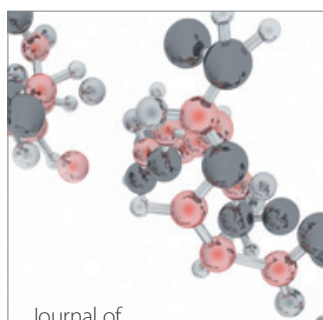

Analytical Methods

in Chemistry

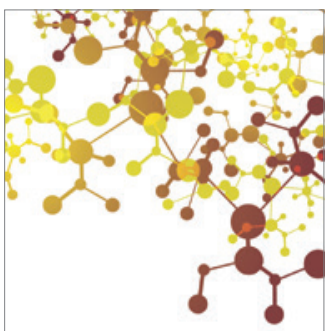

Journal of

Applied Chemistry

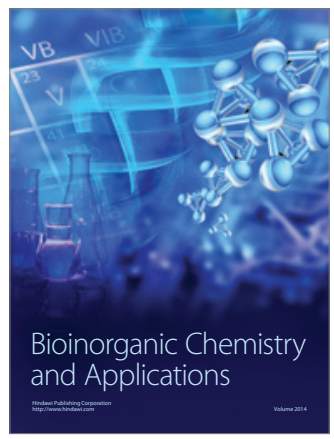

Inorganic Chemistry
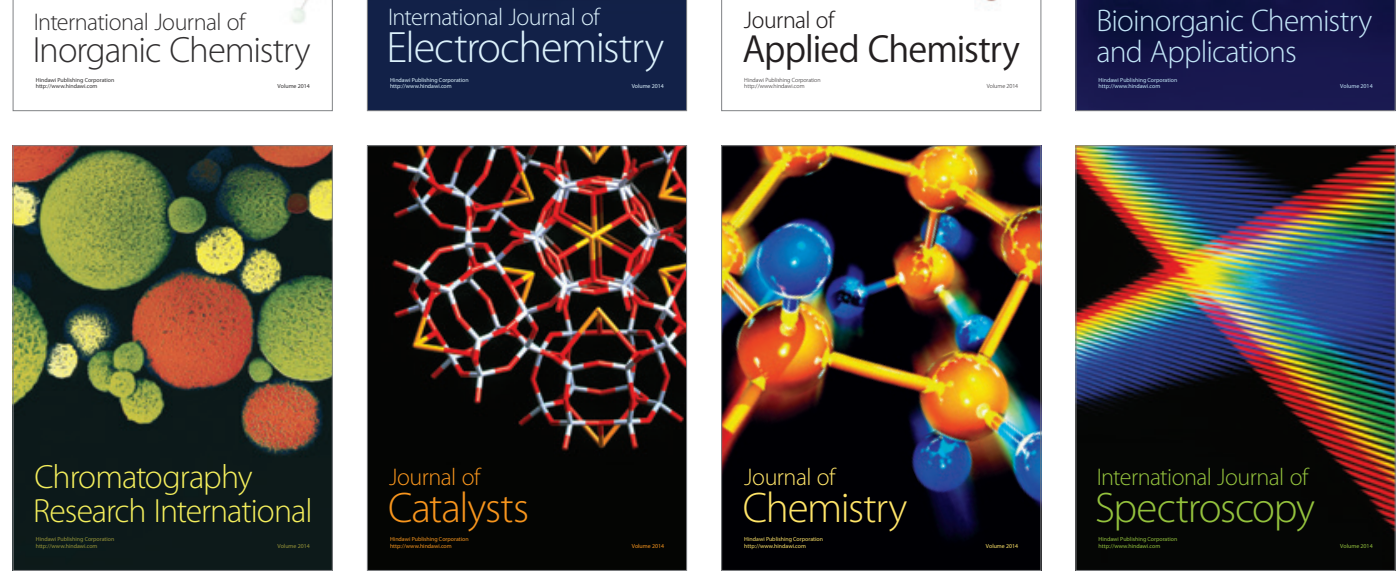